\title{
THE ULAYAT RIGHT TO THE SEA IN ARU ISLANDS DISTRICT OF INDONESIA: A STUDY OF FISHERIES RESOURCES MANAGEMENT BASED ON CUSTOMARY COMMUNITY
}

\author{
Kubangun Nur Aida* \\ Study Program of Sociology, Makassar State University, Indonesia \\ Agustang Andi, Adam Arlin \\ Makassar State University, Indonesia \\ *E-mail: nuraidakubangun@gmail.com
}

\begin{abstract}
Indigenous peoples in the Aru Islands coastal area manage the potential of coastal and marine resources in a traditional manner known as sea customary rights. This paper analyzed customary rights to the sea in the Aru Islands District. In analysing the problems above, this study used descriptive qualitative methods carried out in Aru Islands Regency, Maluku Province. As for data collection, a series of observations, in-depth interviews and focused group discussions (FGD) have been successfully carried out. Then the results showed that in carrying out the management of the coastal and marine environment, the indigenous community of the Aru Archipelago adheres firmly to the rights of the customary land. Customary rights to the sea are traditions that have been passed down for generations and are respected by indigenous peoples. Customary rights are also part of the conception of customary act regarding land and sea rights to indigenous peoples. However, the current condition is that not all villages in Aru Islands Regency impose sea customary regulations. Villages that enforce marine customary guidance only consist of ten traditional villages with different systems and patterns between one customary village and other customary villages. Some traditional villages such as Luthur Village and Rebi Village impose sea customary guidance based on clan (Fam). While other villages impose sea customary guidance based on their villages. Enforcement of the rules-based on villages in the form of payments for traditional guidance paid by fishermen through the owners of capital.
\end{abstract}

\section{KEY WORDS}

Customary rights, Aru Sea, fish resources, customary law.

The management of coastal resources basically has a goal to improve the welfare of the whole community in a sustainable way, especially the local community who live in the coastal zone (coastal zone). Law No. 27/2007 concerning Management of Coastal Areas and Small Islands has considered the existence of indigenous people to be involved in the management of coastal resources and small islands. Indigenous peoples are a group of coastal communities who have traditionally lived

in geographical areas, have strong links with coastal resources and ownership value system.

The existence of indigenous peoples in coastal areas and outer small islands has an important role in the management of water areas throughout Indonesia. Their presence can help management to be better and useful for the community as well as coastal ecology. Customary use of resources is formed in the institutional system and stratified traditional practices. In the past this use has been guaranteed social justice, upholding social norms through social pressure, sharing and value systems to determine the concepts of ownership and territory and also determine the roles of men and women in rural communities (Bennet 2012). According to Suhana (2008) the main variable in the study the customary rights of the sea are related to (1) the territory, (2) the social ownership unit, (3) the legality together implementation (enforcement). 
The area in the context of regulating customary rights to the sea does not only limited to area restrictions, but also to the exclusivity of regions, which can also be applied to marine resources, the technology used, the level of exploitation and the limits temporal boundaries. Coastal areas can be understood as areas where they meet various interests, both government, corporation, and society in order to utilise resources. Visser (2004), states management of coastal resources (including aquatic resources) requires a cross-interest and stakeholder approach.

Different perceptions and interests have triggered overlapping authority and conflict of interest in the application of coastal area management regulations. Bromley (2001) state that the confusion of ownership and control of coastal resources has been causing legal uncertainty in managing coastal areas. The local community assumes that there is no owner of coastal resources so that the potential exists accessed and utilized by anyone (open access). Interaction between access and ownership can raise conflicts over rights issues. In the long run, the issue of this right can lead to behavior that has the potential for infringement relating to the certainty of rights. Besides that, this interaction pattern also gives rise to action and certain activities that will be carried out by business actors to maximize their benefits.

Indonesian people have local wisdom in managing resources. In some areas in Maluku, Papua, Raja Ampat knows a form of local wisdom in the form of Sasi (law) for natural resource management. The management model considers aspects of sustainability this natural resource has been known and practiced from generation to generation (Handayani 2008; McLeod et al. 2009). In villages that still maintain the tradition of Sasi, in the waters are still easy to find fisheries commodities of high economic value like lola and sea cucumber; on the contrary, the village has long left the practice of wisdom this locale is very difficult to obtain these biotas (McLeod et al. 2009). The purpose of this study is to identify customary rights to the sea in the aru islands district.

\section{METHODS OF RESEARCH}

This research used a constructionist paradigm. The paradigm views social science as a systematic analysis of the meaning of social action through direct observation (Dedy Mulyana, 2003). The constructionist paradigm is considered to have the ability to solve as an imperfect problem by making a more natural setting, gathering more site information. This research used the descriptive qualitative method. The study was conducted in "Aru Islands Regency" Maluku Province. The data used were primary data and secondary data. Primary data obtained directly from informants and secondary data was the data in the form of authentic reports, documents and information archives, research results and other written sources that support primary data. Data collection was done by observation, in-depth interviews and focused group discussions. The selection of informants was carried out in a purposed sampling technique. The informants included village officials who imposed sea rights on Jurjela Village (Wamar Island, Aru Island District), Luthur Village based on clans (Aru Selatan Aru Selatan District), Rebi Village based on clans (Aru Tengah Timur District), Jirwatu Village, Warabal Village (Aru Tengah Selatan District), Apara Village (Aru Selatan Timur District), Wanger Village (Wamar Island Aru Island District), Wokam Village (Aru Island District), Wasiang Village (Aru Selatan District), Desa Bemong (Aru Selatan District). Data analysis techniques are performed data collection, data analysis, data reduction, data presentation, and drawing conclusions (Neuman, 2003).

\section{RESULTS AND DISCUSSION}

Customary Rights System of Sea Control. Environmental wisdom can be realized in social values, customary norms, ethics, belief systems, traditional spatial planning patterns, and simple environmentally-friendly equipment and technology. Social resources inherited from generation to generation, in fact, proven to be effective in preserving the environment, and ensuring the preservation of the social environment. Indigenous peoples around the coast have a high dependence on the sea and coast. Dependence on resources has driven 
the regulation of customary tenure systems based on prevailing social systems. The relationship of the social system of indigenous peoples with sustainable forests is influenced by the rules, norms and traditional values that have been internalized in the lives of indigenous peoples. Customary rules, norms, and values also regulate rights and access to resources.

Besides rights and access can also be done by outsiders who have the power to gain access to benefits even though they do not have rights (Herrera-Racionero 2014). Customary law communities in coastal areas manage the potential of coastal and marine resources in a traditional manner known as marine customary rights. Compared to customary land rights, it is clear that customary rights to the sea are customary traditions that have been passed on for generations and are respected by indigenous peoples. Customary rights are part of the concept of customary law regarding land and water rights. Access to get the right to use resources is only based on the ability (ability), which describes the strength (a bundle of power). Ownership is based on rights in accordance with recognized claims. So ownership represents the existence of a recognized right (a bundle of right), both legal-formal and informal (Ribot \& Peluso, 2003; Ostrom. 2002). Customary law is formulated as a communistic, religious conception that allows individual land tenure, with rights to land that are personal, as well as containing togetherness (Harsono, 1997).

Customary rights have at least three main elements, namely: (1) the legal community as subject to customary rights; (2) leadership institutions that have public and civil authority over customary rights; and (3) the area which is the object of customary rights, consisting of land, water, and all-natural resources contained therein. The authority and obligations of indigenous and tribal peoples classified in the field of civil law are joint property rights over land and water, while those classified as public law are the duties of authority to manage, regulate and lead the designation, control, use, and maintenance. Customary rights include all land and waters in the jurisdiction of the community concerned both those that have been cursed by someone and those who have not so that in the area of customary rights there is no land or waters (Harsono, 1997).

In the concept of a marine tenure system, 'adat' refers to the concept of customary law, while tenure refers to the social process of interactive activities related to the control of a particular area or access to resources (Bennet, 2012). The customary system of marine tenure is very unique because it consists of a number of unwritten rules that guarantee local ecological knowledge that is integrated in their culture to manage access to fishing grounds and resource stocks (Adaye, 2000 ). Although the customary marine tenure system is effective, there are a number of factors that cause the system to no longer function as a result of modernization and colonization. A number of socio-economic factors include: the inclusion of an economic system based on (money), increased capture capacity due to technological improvements, social change, political and demographic situations, weakening of the power of figures and respect for western customs, religion, and education (Bennet 2012).

Some elements that indicate that there is a marine control area from the coastal customary law community, namely: (a) there is a certain area in the sea where the community takes the necessities of life; (b) the ability to reach these places; (c) carried on from generation to generation; (d) conducted periodically; and (e) always be defended against other parties entering the area without permission from the customary law community. Water area management policies must include the active role of local communities through local institutions (indigenous wisdom) in the protection and preservation of water resources. In carrying out the management of the coastal and marine environment, the indigenous community adheres to the customary law of the sea. Customary sea law is customary rules that are maintained and maintained by fishing communities to maintain order in fishing and the life of fishing communities on the coast. Customary law of the sea can also function as a filler of positive national law if there is no regulation in that national law. The substance of the marine customary method is the fishermen together with their abilities in the form of fishing gear knowledge, management of marine biological resources and the ability to preserve the potential resources available in the wild. 
Marine Resource Management System. Coastal resource management basically has a goal to improve the welfare of the whole community in a sustainable manner, especially the local community who live in the coastal region. Maluku Islands as an area dominated by the sea also influence various actions and mindsets of the people. The existence of indigenous peoples in Maluku has been recognized by the enactment of Regional Regulation (Perda) Number: 14 of 2005 concerning "Re-Stipulation of the Country as a Unit of Customary Law Communities in the Government of Maluku Province". This shows that there is a spirit to revive indigenous peoples in organizing their lives in accordance with traditional values that have been built since ancestors. However, the regional government regulation does not regulate the existence of indigenous peoples with their customary territories. While each customary village generally has a customary area claim.

Naturally, the potential of coastal and marine resources in the area is utilized directly by the people who live in the area, who are generally fishermen. The potential of coastal and marine resources utilized by fishermen is limited to efforts to meet the needs of life. in the view of the islands, the sea as one of the important elements in life, the sea must be guarded and empowered for the interests and welfare of its people. Even though the sea is a free area for anyone, but in the Maluku community rules, not everyone can enjoy this marine product because there is a kind of division in the sea area. The concept of ownership of the marine ownership area in Maluku is called Sasi harbor and free harbor.

The Nolloth and Haruku communities there are two ways to manage the sea area. The first area management is by prohibiting the community outside the owner's village from exploiting the marine resources in it. The ban aims to have outside community recognition of management. As happened in Latuhalat, outside communities are allowed to take marine resources by asking permission in advance from Latuhalat village. While in Kei, in Nolloth and Haruku, a ban on taking marine resources was put into the village's sea harbor (harbor). Sasi as a custom institution in the Moluccas in its development underwent various changes but did not eliminate the basic value of sasi itself. Sasi is implemented as an effort to protect and preserve natural products on land and at sea.

The rules for implementing sasi are accompanied by sanctions imposed by customary law in the form of fines and / or disasters that will befall those who commit violations of the stipulated Sasi. At the time of ancestors, sasi was done by making a traditional ceremony involving traditional institutional instruments and using the terms of the ceremony, among others. Current Conditions Not all villages in Aru Islands Regency impose sea customary regulations. Villages that enforce marine customary guidance only consist of ten traditional villages with different systems and patterns between one customary village and another customary village. some Indigenous Villages such as Luthur and Rebi Village impose seabased customary rules based on clan. While other villages impose sea customary rules based on the village. The application of rules based on the village in the form of payment of traditional regulations paid by the fishermen through the owners of capital. Application of rules based on clan, the capital owner pays to clans. At the time of payment there is a letter of the agreement made between the owner of the capital and the owner of the marine customary ownership, then carried out in accordance with the agreement and the amount of payment given.

Usually, payments range from 5 Million to 50 Million Rupiah. The use of payments for ownership of customary land will be used for the construction of houses of worship and village interests. the application of marine customary land-based on clans uses the funds for clans that have sea customary land. But so far the use of funds has not been felt by the villagers because only certain clans enjoy it. Here follow eleven villages that impose customary guidance on the sea to fishing communities in the Aru island, namely. Jurjela Village is located on Wamar Island, Luthur Village based on Marga is located in South Aru, Rebi Village based on Marga is located in Middle East Aru, Jirwatu Village, Warabal Village is located in Aru Tengah Selatan, Apara Village in Aru Selatan Timur, Wanger Village on Wamar Island. Wokam Village in Aru Islands, Wasiang Village in South Aru, Bemong Village in South Aru. 


\section{CONCLUSION}

In carrying out the management of the coastal and marine environment, the indigenous communities of the Aru Archipelago hold firm to the rights of the Ulayat sea. Customary rights to the sea are traditional cultural habits that have been passed down for generations and are respected by indigenous peoples. Customary rights are part of the concept of customary law regarding land and sea rights to the community of indigenous peoples. Current conditions not all villages in Aru Islands Regency impose sea customary regulations. Villages that enforce marine customary guidance only consist of ten traditional villages with different systems and patterns between one customary village and another customary village. Some Indigenous Villages such as Luthur and Rebi Village impose customary sea rules based on clan (Fam). While other villages impose sea customary rules based on their village. The application of rules based on the village in the form of payment of traditional regulations paid by the fishermen through the owners of capital.

\section{REFERENCES}

1. Bennett G. 2012. Customary marine tenure and contemporary resource management in Solomon Islands. Proceedings of the 12th International Coral Reef Symposium, Cairns, Australia, 9-13 July 2012 22A Cultural, political and historical dimensions of coral reef management.

2. Bromley DW. 2001. Property Regimes and Institutional Change, in Property Rights and Institutional Change. Frederica, Denmark

3. Dedy Mulyana, 2003. Metodologi Penelitian Kualitatif. Bandung, PT Remaja Rosdakarya.

4. Denzin, Norman K. dan Lincoln, Yvonna S, 2009, Handbook of Qualitative Research, diterjemahkan oleh Dariyatno dkk, Pustaka Pelajar, Yogyakarta.

5. Harsono, Budi. 1997. Hukum Agraria Indonesia: Sejarah Pembentukan Undang- Undang Pokok Agraria dan Pelaksanaannya. Jakarta : Djambatan.

6. Handayani. 2008. Kajian terhadap bentuk-bentuk kearifan lokal dalam pengelolaan sumber daya pesisir di Kabupaten Raja Ampat. [Tesis]. Universitas Diponegoro. Semarang.

7. Herrera-Racionero $P$, Lizcano-Fernández E, Miret-Pastor L. 2014. Us and them, Fishermen from Gandía and the loss of institutional legitimacy. Mar Pol. (54) : 130-136.

8. McLeod E, Szuster B, Salm R. 2009. Sasi and marine conservation in Raja Ampat, Indonesia. Coastal Management. 37(6):656-676.

9. Ribot, Jesse C \& Nancy Lee Peluso. 2003. A Theory of Access. Rural Sociology. Vol. 68, Num. 2, pp 153-181.

10. Suhana. 2008. "Belajar dari Suku Bajau dan Kearifan Lokal Desa Autubun Kepulauan Tanimbar Maluku Tenggara Barat." Kebijakan Ekonomi Kelautan pada Pusat Kajian Suberdaya Pesisir dan Lautan. Jakarta: PKSPL-IPB.

11. Visser, EL. 2004. Reflections on Transdisciplinarity, Integrated Coastal Development, and Governance. Didalam : Visser VL, editor. Challenging Coasts Transdisciplinary Excursions into Integrated Coastal Zone Development. Amsterdam (NL) : Amsterdam University Press. 